\title{
BIMBINGAN TEKNIS OLAH DATA DENGAN SPSS 25 UNTUK PARA PEGAWAI KANTOR BKAD KABUPATEN MAJENE
}

\author{
Laila Qadrini, Septiawan Ardiputra, dan Andi Seppewali \\ Universitas Sulawesi Barat
}

E-mail: laila.qadrini@unsulbar.ac.id ; septiawan.ardiputra@unsulbar.ac.id ; andi.seppewali@unsulbar.ac.id

\begin{abstract}
ABSTRAK. Kegiatan Bimbingan Teknis Olah Data dengan SPSS 25 untuk para pegawai Kantor BKAD Kabupaten Majenemerupakan bentuk Kegiatan Pengabdian kepada Masyarakat yang orientasi kegiatannya membimbingParaPegawai Kantor BKAD Kabupaten Majeneuntuk memahami cara pengolahan Data SPSS dalam rangka penyelesaian Tugas Akhir/ Tesis sebagai Mahasiswa Pascasarjana. Bentuk kegiatan pengabdian ini terdiri dari 1) Tahap Observasi yaitu Mengidentifikasi calon peserta bimbingan teknis pada Kantor BKAD Kabupaten Majene. 2) Tahap Persiapanyaitu pelaksanaan kegiatan Bimbingan Teknis pada Kantor BKAD Kabupaten Majene,3) Tahap Pelaksanaan Bimbingan Teknis. Dengan terlaksananya kegiatan ini beberapa Pegawai pada Kantor BKAD Kabupaten Majeneyang sedang proses penyelesaian Tugas Akhir/Tesis agar mendapatkan Bimbingan Teknis Olah Data SPSS 25 yang diharapkan dapat berdampak pada peningkatan kemampuan dalam Pengolahan Data SPSS dan pemahaman interpretasi output data tesis dengan SPSS 25.
\end{abstract}

Kata kunci: Bimbingan Teknis; Pegawai BKAD; SPSS 25; Olah Data

\section{TECHNICAL COUNSELING OF DATA PROCESSING WITH SPSS 25 FOR SOME EMPLOYEES OF THE BKAD OFFICE OF MAJENE DISTRICT}

\begin{abstract}
The Technical Guidance Activity for Processing Data with SPSS 25 for employees of the BKAD Majene Regency is a form of Community Service Activities whose activity orientation is to guide the employees of the BKAD Majene Regency Office to understand how to process SPSS data in order to complete the Final Project / Thesis as a Postgraduate Student. The form of this service activity consists of 1) Observation Stage, namely identifying potential technical guidance participants at the BKAD Majene Regency Office. 2) The Preparation Stage, namely the implementation of the Technical Guidance activities at the BKAD Majene Regency Office, 3) The Technical Guidance Implementation Stage. With the implementation of this activity, some employees at the BKAD Majene Regency office who are in the process of completing their Final Project / Thesis or while studying are receiving SPSS 25 Data Processing Technical Guidance which is expected to have an impact on increasing their ability in SPSS Data Processing and understanding the interpretation of thesis data output with SPSS 25.
\end{abstract}

Key words: Technical Guidance; BKAD Employees; SPSS 25; Data Processing

\section{PENDAHULUAN}

Hak untuk memperoleh pendidikan merupakan hak setiap Warga Negara Indonesia.Memperoleh pendidikan formal lanjutan merupakan hak PNS maka dari itu untuk meningkatkan kemampuan dan profesionalisme Pegawai Negeriberbasis kompetensi, hal ini diatur pada Surat Edaran Menpan RB Nomor 4, Tahun 2013tentang mengembangkan SDM Aparatur perlu mendorong setiap aparatur untuk rnengernbangkan diri dan meningkatkan kemampuan serta profesionalisrne Pegawai Negeri Sipil berbasis kompetensi melalui pendidikan lanjutan dalam bentuk pemberian tugas belajar dan izin belajar dari jenjang Diploma melanjutkan ke jenjang Sarjana, dan dari Sarjana melanjutkan studi ke jenjang PascaSarjana, Pegawai Negeri Sipil yang diberikan tugas belajar selaku Mahasiswa Program Pascasarjana Strata Dua akan dianggap berkontribusi terhadap keilmuan ketika para peserta menulis skripsi atau tesis. Untuk Mahasiswa Program Pascasarjana Strata Dua dipersyaratkan membuat tesis untuk mendapatkan gelar magister. Karya ilmiah berupa tulisan merupakan karya yang paling mudah dipelajari oleh semua orang. setiap mahasiswa atau orang yang ingin mempelajari bidang ilmu tersebut tinggal datang ke perpustakaan dan membaca karya ilmiah dalam bentuk tulisan. Digitalisasi membuat segala hal serba mudah, salahsatunya adalah kemudahan akses yang sekarang terjadi begitu cepat (Amalia, 2019). Tentunya alasan kepraktisan dalam penyebaran keilmuan juga menjadi pertimbangan bahwa sebuah karya tulis perlu dihasilkan. terlebih pada era digiital setiap orang dapat mempelajari hasil karya ilmiah kapanpun dan dimanapun.Pada prinsipnya pengolahan data pada karya ilmiah berupa skripsi atau tesis sangat dibutuhkan bantuan teknologi(Wanto \& Damanik, 2015). Apabila kita melakukannya secara manual akan sangat susah penghitungannya karena biasanya data yang akan disajikan dalam survei berskala besar apalagi sensus yang mencakup seluruh Indonesia selain itu rumus-rumus yang digunakan juga cukup rumit. Dengan adanya kemajuan teknologi ini telah diciptakan beberapa Software statistik yang sangat berguna. Software statistik itu sendiri adalah suatu 
perangkat lunak yang dibuat untuk memudahkan dalam melakukan pengolahan serta penyajian data(Yamin \& Kurniawan, 2009). Untuk itu, wajib sekali bagi para mahasiswa tingkat akhir untuk bisa menggunakan perangkat lunak ini. Proses menganalisis dan menginterpretasikan data erat kaitannya dengan pengolahan data.Kebanyakan tesis para pegawai BKAD Majene adalah mengolah data dengan SPSS, Namun para pegawai BKAD Majene mengaku kesulitan belajar dan kurang memiliki waktu untuk memahami cara olah data dengan SPSS disebabkan oleh kesibukan bekerja, perjalanan dinas dan lain-lain. Hal ini dapat menyebabkan praktek plagiarisme meningkat karena para peserta bimbingan teknis dalam hal ini para pegawai BKAD Kabupaten Majene yang sedang kuliah S2 lebih banyak menjiplak tesis orang lain, dan Ketika ujianpara peserta tidak bisa menginterpretasikan hasil olah data dan tujuan tesis para peserta dengan baik, Oleh karena itu, kami selaku dosen di Universitas Sulawesi Barat pada Program Studi Matematika dan Program Studi Ilmu Politik mengadakan kegiatan "Bimbingan Teknis Olah Data dengan SPSS 25 untuk para Pegawai BKAD Majene" sebagai salah satu wujud Pengabdian kepada Masyarakat.

\section{METODE}

Kegiatan Pengabdian Kepada Masyarakat (PKM)ini bertujuan agar peserta bimbingan teknis dalam hal ini para pegawai BKAD Kabupaten Majene memahami dasar Ilmu Statistika dan landasan penelitian, memahami jenis data dan memahami cara menurunkan rasio kesamaan tesis dengan tesis yang lainnya.

sasaran kegiatan, yaitu para pegawai BKAD Kabupaten Majene. Keseluruhan kegiatan berdurasi selama dua hari diawali dengan observasi awal untuk masukanrancangan detail kegiatan. Kegiatan PKM inimenggunakan pendekatan bersifat persuasifedukatif tanpa mengikuti satu metode pembelajaran tertentu, meskilebih mendekati metode praktikum, pada kegiatan ini terdapat presentasi hasil olah data yang ada pada tesis oleh masing masing peserta bimbingan teknis, peserta dan pemateri melakukan diskusi dan tanya jawab perihal tayangan dari presentasi tiap peserta, Berikut adalah tahapan bimbingan teknis:

\section{Tahap Observasi}

Tahap Observasi dimulai dengan mengadakan diskusi dengan beberapa pegawai BKAD Majene yang berkonsultasiterhadap salah satu tim pengabdian tentang kendala yang dihadapi dalam memahami output SPSS tesisnya, dan diadakan permintaan pemateri dari para pegawai BKAD Majenetentang bimbingan teknis olah data dengan SPSS $25 \mathrm{ke}$ beberapa dosen yang sekiranya kompeten dibidang Statistika di Unsulbar.

\section{Tahap Persiapan}

Tahap persiapan dimulai dengan mengklasifikasikan topik tesis para peserta. Kami sebagai tim pengabdian mengumpulkan tesis dari para pegawai BKAD Kabupaten Majene. Dan mengklasifikasikan topik tesis para peserta sesuai jenis analisis data statistiknya.

\section{Tahap Pelaksanaan}

Tahap pelaksanaan kegiatan dilakukan dengan membimbing secara teknis para peserta mulai dari tahap pengumpulan data, preprocessing data, menganalisis deskriptif data, dan Teknik analisis data berupa menguji reliabilitas dan validitas kuesioner, dan menginterpretasikan hasil analisis data dari SPSS 25.

Menyadari bahwa bimbingan teknis yang digelar selamasatu hari tidak akan memberikan dampak yang bersinambungan, maka kami memutuskan untuk menambah tahapan pelaksanaan yang tadinya berorientasi untuk mengetahui dan mengidentifikasikendala pada analisis data tesis para peserta namun selanjutnya dengan menuntun para peserta dalam hal ini para pegawai BKAD Majene tiap-tiap tahap mengolah data dengan SPSS 25 dan melakukan tanya jawab perihal interpretasi data dari output SPSS 25 agar capaian kegiatan bimbingan teknis ini bisa maksimal yaitu dengan tersampaikannya ilmu dari kami selaku pemateri terhadap peserta bimbingan teknis sebagai wujud pengabdian masyarakat, untuk selanjutnya dibahasdalam Hasil dan Pembahasan.

\section{HASIL DAN PEMBAHASAN}

Para pegawai BKAD Majene menyampaikan kendala para peserta tentang pengolahan data SPSS dan interpretasi output hasil analisis dengan SPSS 25, dan para peserta berinisiatif untuk menyurat keProdi Statistika Unsulbar untuk mengirimkan beberapa dosen yang kompeten dalam hal pengolahan data dengan SPSS, dan kami memilih SPSS 25 sebagai Software yang dipakai untuk bimbingan teknis pengolahan data. kegiatan bimbingan teknis ini diawalidenganpengamatan sejauhmanapengetahuan para pegawai BKAD Kabupaten Majene tentang tesis yang peserta buat, Kami mengidentifikasi topik tesis para peserta, topik tesis para peserta kebanyakan berupa topik analisis regresi, analisis jalur dan analisis SEM. Kami mengumpulkan topik tesis para peserta yang sekiranya sama analisisnya, dan kami mengklasisikasikan topik-topik tesis tersebut. Pengolahan data mencakup preprocessing data, analisis data deskriptif, uji relibilitas dan validitas kuesioner, dan olah data. Kami memandu 
peserta untuk preprocessing data. Berdasarkan hasil pengamatan awal kami telah menunjukkan adanya tingkat pengetahuan yang rendah terhadap pemahaman interpretasi data, Kami mengidentifikasi topik tesis para peserta, topik tesis para peserta kebanyakan berupa topik analisis regresi, analisis jalur dan analisis SEM. Kami mengumpulkan topik tesis para peserta yang sekiranya sama analisisnya, dan kami mengklasisikasikan topik-topik tesis tersebut.Teknik Pengumpulan Data juga peserta mesti memahaminya terlebih dahulu agar tidak peserta mengerti data yang seperti apa yang akan diteliti,

Adapun jenis data adalah Data Primer dan data sekunder, Data primermerupakan datayang diperoleh dengan survey lapangan yang menggunakansemua metode pengumpulan data original (Kuncoro, 2013, p.127). Data sekunder adalah data yang telah dikumpulkan oleh lembaga pengumpul data dan dipublikasikan kepada masyarakat pengguna data (Kuncoro, 2013, p.127).

Kami melakukan preprocessing data, preprocessing data adalah pemrosesan awal data meliputi Pembersihan data, Mengisi nilai-nilai yang hilang, menghaluskan noisy data, mengenali atau menghilangkan outlier, dan memecahkan ketidak konsistenan, dan mereduksi data yang banyak, selanjutnya kami melaksanakan Analisis Statistik Deskriptif. Menurut Malhotra (2005), analisis deskriptif merupakan metode analisis yang digunakan dengan tujuan untuk memperoleh gambaran obyektif mengenai obyek penelitian serta untuk mengetahui seberapa banyak responden menyatakan hal yang sama terhadap suatu obyek pertanyaan. Peserta banyak menulis topik tesis yang berkaitan dengan kinerja pegawai namun kurang memahami apa hubungan antara variabel penjelas dan variabel terikat dan bagaimana interpretasi variabel penjelas yang mempengaruhi variabel terikat misalnya apakah gaya kepemimpinan mempengaruhi kinerja pegawai dan seberapa besar kontribusi gaya kepemimpinan mempengaruhi kinerja pegawai. Teknik Analisis Data Untuk menjawab masalah yang dirumuskan dalam penelitian, maka teknik analisis data yang digunakan adalah Uji Validitas dan uji reliabilitas. Uji validitas digunakan untuk mengukur sah atau valid tidaknya suatu kuesioner. Suatu kuesioner dikatakan valid jika pertanyaan dan kuesioner mampu untuk mengungkap sesuatu yang akan diukur oleh kuesioner tersebut (Ghozali, 2011). Uji validitas menggunakan analisis korelasi pearson, keputusan mengetahui valid tidaknya butir instrumen. Jika pada tingkat signifikan $5 \%$ nilai $\mathrm{r}$ hitung $>\mathrm{r}$ tabel maka dapat disimpulkan bahwa butir instrumen tersebut valid. Uji Reliabilitas adalah alat untuk mengukur suatu kuesioner yang merupakan indikator dari suatu variabel. Suatu kuesioner dikatakan reliabel atau handal jikajawaban pertanyaan adalah konsisten atau stabil dariwaktu ke waktu (Ghozali, 2011). Suatu konstruk atauvariabel dikatakan reliabel jika memberikan nilaiCronbach Alpha $>0,60$.

Uji t digunakan untuk mengetahui pengaruh masing-masing variabel independen terhadap variabel dependen (Widjarjono, 2010).

a. Merumuskan hipotesis

$\mathrm{H} 0: \beta \mathrm{i}=0$, artinya variabel bebas secara parsial tidakmemberikan pengaruh signifikan terhadap variabel terikat

$\mathrm{H} 1: \beta \mathrm{i} \neq 0$, artinya variabel bebas secara parsial memberikanpengaruh signifikan terhadap variabel terikat

a. Menetapkan besarnya level of significance $(\alpha)$ sebesar 0,05 .

b. Mengambil Keputusan(dengan nilai signifikansi) 1 . Jika nilai signifikansi $>$ dari pada 0,05 , maka $\mathrm{H} 0$ diterima dan $\mathrm{H} 1$ ditolak

2. Jika nilai signifikansi $<$ daripada 0,05 , maka $\mathrm{H} 0$ ditolak dan $\mathrm{H} 1$ diterima

Uji F, Menurut Kuncoro (2009), uji F digunakan untuk menguji signifikan tidaknya pengaruh variabel bebas secara simultan terhadap variabel terikat.

a. Merumuskan hipotesis.

$\mathrm{H} 0$ : Seluruh variabel bebas tidak berpengaruh signifikansecara simultan terhadap variabel terikat

H1 : Seluruh variabel berpengaruh signifikan secarasimultan terhadap variabel terikat

b. Menetapkan besarnya nilai level of significance $(\alpha)$ yaitu sebesar 0,05 .

c. Mengambil Keputusan (dengan nilai signifikansi)

1) Jika nilai signifikansi $>$ dari pada 0,05 , maka H0 diterima dan H1ditolak

2) Jika nilai signifikansi $<$ daripada 0,05 , maka H0 ditolak dan H1 diterima

Kegiatan Bimbingan Teknis Olah Data dengan SPSS 25 bagi para Pegawai BKAD Kabupaten Majene adalah salah satu bentuk kegiatan pengabdian kepada masyarakat ini telah terlaksana dengan baik. Kegiatan ini diikuti oleh 8 orang pegawai yang sedang merevisi tesisnya. Kegiatan ini dilaksanakan pada sebanyak 2 (dua) kali pertemuan dengan rincian pelaksanaan kegiatan sebagai berikut: 
Tabel 1. Rincian Pelaksanaan Kegiatan

\begin{tabular}{cccc}
\hline Pert ke - & Hari tanggal & Jam & Kegiatan \\
\hline I & Selasa, 19-02- & $20.00-$ & Identifikasi \\
& 2020 & 23.00 & Topik Tesis \\
\multirow{2}{*}{ II } & Sabtu, 22-02- & $11.00-$ & Mengolah Data \\
& 2020 & 16.00 & \\
\hline
\end{tabular}

\section{SIMPULAN}

Adapun kesimpulan dari kegiatan ini adalah:

1. Setelah mengikuti bimbingan teknis Olah Data dengan SPSS 25 untuk para pegawai BKAD Kabupaten Majene yang sedang mengerjakan tesis telah memberikan hasil berupa pemahaman tentang interpretasi output analisisdata dengan SPSS 25.

2. Setelah mengikuti bimbingan teknis ini peserta yaitu para pegawai BKAD Kabupaten Majene telah melakukan tanya jawab yang dapat memaparkan kendala-kendala selama proses pembuatan tesis dan menemukan solusi untuk bekal saat pembimbingan nanti dengan dosen pembimbing peserta.

3. Bimbingan teknis seperti ini perlu terus diadakan karena banyak para pegawai BKAD Kabupaten Majene yang akan melanjutkan pendidikannya kejenjang S1, S2 dan S3.

\section{DAFTAR PUSTAKA}

Amalia, R. M. (2019). Peningkatan Tingkat Literasi Media Siswa SMAN Jatinangor melalui Kampanye Sosial "Gercep Banget." Jurnal Pengabdian Kepada Masyarakat, 3(4), 8689.
Ghozali, I. (2011). Aplikasi Analisis Multivariat Dengan Program SPSS. Semarang: Universitas Diponegoro.

Kuncoro, M. (2009). Metode Riset Untuk Bisnis \& Ekonomi. Jakarta : Erlangga.

Kuncoro. (2013). MudahMemahamidanmenganalisis Indikator ekonomi. Yogyakarta: UPP STIM YKPN.

Malhotra, Naresh K, (2005), Riset Pemasaran : Pendekatan Terapan, Terjemahan oleh : Soleh Rusyadi

Maryam,MM, Edisi Keempat, Jilid 1 dan 2, PT. INDEKS, Jakarta

Surat Edaran Menpan dan RB Nomor 4, (2013). Pemberian Tugas Belajar dan Izin Belajar

Wanto,A., \& Damanik, H. (2015). Analisis Penerapan Sistem Pendukung Keputusan Terhadap Seleksi Penerima Beasiswa BBM (Bantuan Belajar Mahasiswa) Pada Perguruan Tinggi Menggunakan Metode Simple Additive Weighting (SAW)(Studi Kasus: AMIK Tunas Bangsa Pematangsiantar). Prosiding Seminar Nasional Rekayasa (SNTR) II, 2(25), 323333.

Widjarjono, A. (2010). Analisis Statistika Multivariat Terapan. Yogyakarta: UPP STIM YKPN.

Yamin, S., \& Kurniawan, H. (2009). SPSS Complete: Teknik Analisis Statistik Terlengkap dengan Software SPSS. Jakarta: Salemba Infotek. 